\title{
Effect of Partially De-Oiled Maize Germ Cake Flour on Physico-Chemical and Organoleptic Properties of Biscuits
}

\section{Barnwal P*, Purushottam Kore and Alka Sharma}

Food Grains and Oilseeds Processing Division, Central Institute of Post Harvest Engineering and Technology (CIPHET), Ludhiana-141004, Punjab, India

\begin{abstract}
The present study was conducted to standardize the levels of partially De-oiled Maize Germ Cake flour (DMGC flour) in wheat flour for biscuit preparation. The DMGC flour was incorporated in the traditional recipe to replace wheat flour at levels of DMGC flour by $0,10,20,30,40$ and 50 percent in preparation of biscuits. The prepared biscuits were evaluated for their organoleptic, nutritional, textural and color properties. Sensory evaluation of biscuits showed that $10 \%$ addition of DMGC flour had higher overall acceptability, taste, texture and flavor. The nutritional value of the biscuit as determined through nutrient analysis-moisture $(2.62 \%)$, protein $(8.16 \%)$, fat $(17.74 \%)$, ash $(1.09 \%)$, crude fibre $(1.76 \%)$ and carbohydrate $(68.64 \%)$ with $10 \%$ of DMGC flour was comparable to control (refined wheat flour) biscuit. The color values i.e. $L, a$ and $b$ values varied significantly with DMGC flour incorporation level. The textural properties such as fracture force $(\mathrm{N})$, hardness $(\mathrm{N})$, breaking strength $(\mathrm{N})$, breaking energy $(\mathrm{N}-\mathrm{mm})$, cutting strength $(\mathrm{N})$ and cutting energy $(\mathrm{N}-\mathrm{mm})$ increased with DMGC flour incorporation level up to $30 \%$. The DMGC flour may be used in manufacture of highly nutritious (viz protein and fibre) biscuits.
\end{abstract}

Keywords: Maize; Germ; De-oiled maize germ cake flour; Chemical composition; Biscuits

\section{Introduction}

Biscuits are convenient food products, becoming very popular among both rural and urban populations across the world. Some of the reasons for such wide popularity are low cost relative to other processed foods, varied taste and longer shelf life. Biscuits have also been considered a better vehicle of fortification with protein because of their popularity, high nutrient density and long shelf-life [1]. In biscuit making, the principal ingredients are wheat flour, sugar, fat, water and salt. These are mixed together with other minor ingredients (baking powder, skimmed milk, emulsifier and sodium metabisulphite) to form dough containing a gluten network [2]. Soft wheat flours are normally used for biscuit preparation, but they can also be made with non-wheat flours such as sorghum, maize, pearl millet etc. In recent years, there has been an increased consumer interest and demand for low fat and high fibre food products. High fat intake is associated with various health disorders such as obesity, cancer, high blood cholesterol, and coronary heart disease [3].

Maize (Zea Mays L.) is an important staple food in many countries of the world and the acreage and production of maize in the world have been increasing continuously. India is the fifth largest producer of maize in the world contributing 3\% of the global production. Maize is processed commercially using two main processes, wet or dry milling; and recently, to a lesser extent, by dry grinding for ethanol production. In both dry and wet milling processing of maize, the germ is separated from the kernel for oil production [4]. Defatted maize germ cake (DMGC), a byproduct of the corn oil industry, is almost entirely used for animal feed. The use of this relatively low-cost ingredient warrants further research for exploiting its potential use in human foods. The maize germ, which accounts for 5-14\% of the weight of a maize kernel, depending on variety and grain size, is high in protein content, dietary fiber and minerals [5-7]. The proteins in DMGC flour mostly consist of albumin and globulin [8,9] and are balanced in most of the essential amino acids; [6] lysine, a major limiting amino acid in wheat, accounts for $5-6 \%$ of the total proteins in DMGC flour, which is more than twice than that in wheat flour. The protein content and the contribution that essential amino acids make to the total are the most important factors from a nutritional point of view [10]. Besides nutritional considerations, the functional properties of flours, such as emulsifying properties, foaming capacity and stability, water and oil absorption, and solubility also contribute significantly to the final quality of a processed food product. The defatted maize germ meal or flour has been studied previously for quality characteristics or in product development $[6,7]$. The maize germ protein flour has been shown to have excellent water retention and fat binding capacity which helps stabilize emulsions by absorbing or binding excess water subsequently leading to higher yield of end products [11].

Being a rich source of good quality protein, there is potential for a wide range of uses of DMGC flour for various food products for human consumption [6]. Very little research has been done to promote DMGC flour use in food formulations, although its use as a food ingredient has been often proposed [6,12-14]. In developing new food products, it is important to balance the quality and quantity of protein that offer optimum processing functionality, nutritional value and cost-effectiveness. While DMGC is mainly used as a feed, with limited additional food uses, DMGC flour has the potential to be used as a fortificant in different food systems such as baked and extruded food products. However, acceptable physico-chemical characteristics and sensory properties are essential in product development endeavors for successful marketing of any newly developed products with added DMGC flour. The main objectives of this study were to evaluate the quality characteristics of biscuits made with different levels of added DMGC flour.

*Corresponding author: P. Barnwal, Food Grains and Oilseed Processing Division, Central Institute of Post Harvest Engineering and Technology (CIPHET), Ludhiana-141004, Punjab, India, E-mail: pbarnwal@rediffmail.com

Received December 06, 2012; Accepted February 27, 2013; Published March 05, 2013

Citation: Barnwal P, Kore P, Sharma A (2013) Effect of Partially De-Oiled Maize Germ Cake Flour on Physico-Chemical and Organoleptic Properties of Biscuits. J Food Process Technol 4: 221. doi:10.4172/2157-7110.100022

Copyright: (c) 2013 Barnwal P, et al. This is an open-access article distributed under the terms of the Creative Commons Attribution License, which permits unrestricted use, distribution, and reproduction in any medium, provided the original author and source are credited. 


\section{Materials and Methods}

\section{Preparation of partially de-oiled maize germ cake flour (DMGCF)}

Maize germ was procured from Central Institute of Post-harvest Engineering \& Technology (CIPHET), Ludhiana, India. Proximate analysis of maize germ was carried out using standard procedures [15]. The initial moisture content of maize germ was found as $4.9 \% \mathrm{wb}$ and conditioned to $9 \%$ moisture content on wet basis. Conditioned maize germs were tempered for overnight to achieve moisture equilibration. The conditioned maize germs were subjected to Komet single screw oil expeller (Model CA59G; IBG Monforts Oekotec, Germany) for oil extraction. Partially de-oiled maize germ cake was dried in tray dryer and ground in laboratory grinder cum mixer to obtain de-oiled maize germ cake flour (DMGCF). The flour samples were stored in polyethylene bags at $23^{\circ} \mathrm{C}$ until required for further analysis. The proximate composition i.e. moisture, fat, protein, ash, crude fibre and carbohydrate of partially DMGCF and refined wheat flour were analyzed by standard procedures [15].

\section{Preparation of biscuits}

De-oiled maize germs cake flour was incorporated in the traditional recipe to replace refined wheat flour at levels of 10, 20, 30, 40 and 50\% in preparation of biscuits. Refined wheat flour biscuits were considered as control. Biscuit dough was prepared according to the following formula: $100 \mathrm{~g}$ flour (contain different proportion of DMGC flour and wheat flour, $28 \mathrm{~g}$ sugar, $25 \mathrm{~g}$ shortening, $1.6 \mathrm{~g}$ skim milk powder, $1.6 \mathrm{~g}$ glucose, $0.6 \mathrm{~g}$ sodium chloride, $0.5 \mathrm{~g}$ sodium bicarbonate, $0.8 \mathrm{~g}$ ammonium bicarbonate, $0.5 \mathrm{~g}$ baking powder, and various proportion of water to make required consistency of dough. Biscuit dough was made in a laboratory mixer (Hobart mixer, Model N50, Canada). Fat and sugar were creamed in a mixer with a flat beater for $2 \mathrm{~min}$. The flour containing various proportion of DMGCF, which had been sieved twice with baking powder along with other dry ingredients i.e. glucose, ammonium bicarbonate, sodium bicarbonate, common salt and with required amount of water was added and mixed for $5 \mathrm{~min}$ to make soft dough. The prepared dough after resting (15 min at room temperature) was subjected to sheeting of $2 \mathrm{~mm}$ thickness manually. Finally sheets were cut to $4 \times 4 \mathrm{~cm}$ using the die and were subjected to baking at $180^{\circ} \mathrm{C}$ for $14 \mathrm{~min}$. The well baked biscuits were removed from the oven, cooled to room temperature, packed and stored in air tight container till further use.

\section{Physico-chemical analysis of biscuits}

Proximate composition: The moisture, ash, fat, crude protein and crude fiber of the samples were determined by the standard procedure [15]. Carbohydrate content was estimated by difference.

Color measurement: Changes in the crust color of biscuit by the incorporation of partially DMGC flour were measured by CIE color values [ $\mathrm{L}^{\star}$ (lightness), $\mathrm{a}^{\star}$ (redness), $\mathrm{b}^{*}$ (yellowness)] using Hunter colorimeter D-65 illuminant and $10^{\circ}$ observer. The equipment (Mini Scan XE Plus, Model 45/0-S, Hunter Associates Laboratory Inc, Reston, VA, USA) was calibrated using white and black standard ceramic tiles. Samples were taken and pressed one by one against instrument (sample) port, making sure that it is completely covered by the area to be measured. Five readings for each variation of sample were taken. Measurement was made at the four points on biscuits. The data thus obtained was used to calculate the chroma and hue angle as follows [16]:

\section{Hue angle $\left({ }^{\circ}\right)=\tan ^{-1} \mathrm{~b} / \mathrm{a}$ \\ Chroma value $\left(\mathrm{C}^{\star}\right)=\left(\mathrm{a}^{2}+\mathrm{b}^{2}\right)^{1 / 2}$}

Textural properties: Textural attributes like hardness $(\mathrm{N})$, breaking strength $(\mathrm{N})$ (peak breaking force), breaking energy $(\mathrm{N}-\mathrm{mm})$, fracture force $(\mathrm{N})$ and toughness $(\mathrm{N}-\mathrm{mm})$ of biscuits were measured $[17,18]$ using Texture Analyzer (Model TA-HDi Stable Micro Systems, Surrey, UK).

The hardness of biscuits was measured by using cylindrical stainless probe $\mathrm{P}_{2}(2 \mathrm{~mm}$ dia). Texture Analyzer settings were kept same for all the tests (pre-test speed $3 \mathrm{~mm} \mathrm{sec}^{-1}$, test speed $2 \mathrm{~mm} \mathrm{sec}^{-1}$, post test speed $10 \mathrm{~mm} \mathrm{sec}^{-1}$, distance $5 \mathrm{~mm}$, trigger type auto $5 \mathrm{~g}$ and data acquisition rate $200 \mathrm{pps}$ ). The individual samples of biscuits were placed on the base plate and the probe was attached to the crosshead of the instrument. The peak force and absolute peak force from the forcedeformation curve were considered as fracture force and hardness of biscuits, respectively.

Breaking test and cutting properties was conducted using HDP/ BSK blade set with knife of texture analyzer. The individual samples of biscuits were placed on the base plate such that these were supported at two points and the blade was attached to the crosshead of the instrument. This test simulates the evaluation of hardness by consumer holding the biscuit in hands and breaking the same by bending. The absolute peak force from the resulting curve is the breaking strength of the biscuit whereas area under the curve is peak breaking energy. The peak force from the resulting curve, obtained from blade set with knife, is cutting strength of the biscuit and the area under the peak force on the graph is peak cutting energy.

Organoleptic evaluation: Sensory characteristics of biscuits were evaluated for different sensory attributes by a panel of semi trained twenty five panelists. Sensory attributes like appearance and color, texture, flavor, taste and overall acceptability for all samples were assessed using nine point hedonic scales (IS: 6273, 1971). Hedonic scale was in the following sequence: like extremely-9, like very much-8, like moderately-7, like slightly-6, neither like nor dislike-5, dislike slightly-4, dislike moderately-3, dislike very much-2, dislike extremely-1 [19].

Statistical analysis: The data obtained from the experiments were statistically analyzed for analysis of variance (ANOVA) with single factor analysis using LSD of AgRes Statistical software (Version 3.01, Pascal International Software Solution, USA).

\section{Results and Discussion}

\section{Effect of DMGC flour Level on proximate analysis of biscuits}

Chemical composition of maize germ, refined wheat flour and DMGCF is given in table 1 and for biscuits results are summarized in table 2. DMGCF is a rich source of protein thus, after extraction of oil a good amount of protein and ash was obtained in its flour. From the result, it is evident that there was decrease in carbohydrates level while increase in ash, moisture content, crude fat and protein level for DMGC flour fortified biscuits. There was a change in moisture content from $2.31 \%$ to $3.91 \%$, ash from $0.70 \%$ to $4.39 \%$, crude fat from $13.68 \%$ to $23.13 \%$, protein from $4.23 \%$ to $12.29 \%$ and carbohydrates from $78.57 \%$ to $52.51 \%$. The increase in moisture content can be attributed due to the increased protein content that also increases the water binding capacity of dough with higher levels of DMGCF. It is also reported that with the addition of mustard flour moisture content of biscuits increased slightly [17]. Similarly, increasing levels of millet flour in soy millets biscuits resulted in an increase in moisture content 


\begin{tabular}{|c|c|c|c|}
\hline Parameter(\%) & Maize germ & DMGCF & Wheat flour \\
\hline Moisture & 5.80 & 8.83 & 13.12 \\
\hline Fat & 32.37 & 15.51 & 1.84 \\
\hline Protein & 14.74 & 19.94 & 11.83 \\
\hline Ash & 7.73 & 4.69 & 1.02 \\
\hline Crude fibre & 4.05 & 9.84 & 1.91 \\
\hline Carbohydrate & 35.98 & 41.64 & 70.28 \\
\hline
\end{tabular}

Table 1: Proximate composition of Maize germ, DMGC flour and wheat flour.

\begin{tabular}{|c|c|c|c|c|c|c|}
\hline $\begin{array}{c}\text { DMGCF in flour } \\
\text { blends (\%) }\end{array}$ & Moisture & Protein & Fat & Ash & $\begin{array}{c}\text { Crude } \\
\text { fiber }\end{array}$ & Carbohydrate \\
\hline 0 & $2.31^{\mathrm{e}}$ & $4.23^{\mathrm{f}}$ & $13.68^{\mathrm{f}}$ & $0.70^{\mathrm{e}}$ & $0.57^{\mathrm{f}}$ & $78.57^{\mathrm{a}}$ \\
\hline 10 & $2.62^{\mathrm{d}}$ & $8.16^{\mathrm{de}}$ & $17.70^{\mathrm{d}}$ & $1.09^{\mathrm{de}}$ & $1.76^{\mathrm{e}}$ & $68.64^{\mathrm{c}}$ \\
\hline 20 & $2.77^{\mathrm{d}}$ & $9.02^{\mathrm{cd}}$ & $18.93^{\mathrm{c}}$ & $2.75^{\mathrm{c}}$ & $2.19^{\mathrm{d}}$ & $64.41^{\mathrm{d}}$ \\
\hline 30 & $3.19^{\mathrm{c}}$ & $10.16^{\mathrm{bc}}$ & $22.27^{\mathrm{b}}$ & $3.41^{\mathrm{b}}$ & $2.72^{\mathrm{c}}$ & $58.21^{\mathrm{e}}$ \\
\hline 40 & $3.64^{\mathrm{b}}$ & $11.53^{\mathrm{ab}}$ & $22.74^{\mathrm{a}}$ & $3.96^{\mathrm{a}}$ & $3.15^{\mathrm{b}}$ & $54.91^{\mathrm{f}}$ \\
\hline 50 & $3.91^{\mathrm{a}}$ & $12.29^{\mathrm{a}}$ & $23.13^{\mathrm{a}}$ & $4.39^{\mathrm{a}}$ & $3.76^{\mathrm{a}}$ & $52.51^{\mathrm{g}}$ \\
\hline
\end{tabular}

Mean values with the same superscript letters within the same column do not diffe significantly $(p>0.05)$.

Table 2: Proximate composition of biscuits incorporated with DMGCF.

[20]. Thus it can be concluded that fortification had a positive effect on overall nutritional quality of biscuits since proteins and ash increased significantly as shown by the statistical analysis.

\section{Effect of DMGC flour Level on color parameters of biscuits}

The results obtained are shown in figure 1 . There was a decrease in $\mathrm{L}$ values from 70.77 to 62.86 while an increasing trend was seen for ' $\mathrm{a}$ ' and 'b' values from 6.89 to 11.39 and 27.66 to 33.27 respectively. It was observed that increasing levels of DMGC flour lead to the darkening of biscuits which is supported by decreasing $\mathrm{L}$ and increasing ' $a$ ' and 'b' color values. Similarly, darkening was found in virgin coconut meal fortified biscuits with increasing levels of virgin coconut meal [21]. Decline in L values signifies that with increase in percentage incorporation the lightness decreased while 'a' and ' $b$ ' values shows an increase in redness and yellowness in biscuits. It was reported that with an increase in protein content there is a decrease in $L$ value [22]. The hue angle and chroma value varied from 70.65 to 77.31 and 28.93 to 35.12 respectively. The color development is contributed by Maillard reaction i.e. reaction between sugars and proteins of product that results in brown color [23]. Other factors that may be responsible for color development are time and temperature of baking, composition, humidity in oven, oven type.

\section{Effect of DMGC flour Level on organoleptic properties of biscuits}

The effect of increasing DMGC flour levels on sensory parameters of biscuits were depicted in table 3. Consumer panel sensory scores of biscuit appearance and color were not significantly different from the control (Table 3). The statistical analysis showed that there was not much significant difference in all other sensory parameters i.e. flavor, texture, taste and overall acceptability even after substitution of DMGC flour (up to $30 \%$ ) compared to control. For all the parameters, the scores given by panelists were found in the range of 6.0 to 7.54 , which is quite an acceptable range. Consumer acceptance regarding flavor, texture, taste and overall acceptability was significantly $(P<0.05)$ higher for biscuits prepared from control and 10\% DMGCF versus those prepared with $20 \%, 30 \%, 40 \%$ and $50 \%$ DMGCF fortification. As the level of DMGCF fortification increased after 30\%, the scores for biscuit sensory texture decreased accordingly. The results for biscuit sensory texture support the data on objective texture, measured as breaking strength (Figure 2). Although, overall acceptability scores for cookies prepared from $>10 \%$ DMGC flour were significantly lower than that of control, yet all the scores were $>5$, that is, better than "neither like nor dislike" indicating acceptability of DMGCF fortification. Biscuits with $10 \%$ DMGC flour were more acceptable in organoleptic evaluation. The sensory properties of cookies made with corn gluten meal fortification was studied and reported that cookies with good aroma and crispiness could be prepared with flour blends having DMG meal at levels as high as $20 \%$ [24]. In another study [25], cookies made with $15 \%$ supplementation of defatted wheat germ flour in wheat flour showed sensory scores in the acceptable range. The general composition of defatted wheat germ is similar to DMG $[6,12]$.

\section{Effect of DMGC flour Level on textural properties of biscuits}

The textural parameters are one of the most important quality attributes which affects the overall quality and hence demand of biscuits. The instrumental textural profile analysis is conducted to confirm and improve the textural properties as obtained from subjective evaluation of texture. The textural parameters i.e. fracture force $(\mathrm{N})$, hardness $(\mathrm{N})$, breaking strength $(\mathrm{N})$, breaking energy $(\mathrm{N}-\mathrm{mm})$, cutting strength $(\mathrm{N})$ and cutting energy $(\mathrm{N}-\mathrm{mm})$ are represented in figure 2 . An increasing trend was observed for all the textural parameters up to $30 \%$ level of DMGC flour incorporation and after that the textural parameters were found to decrease with increase in DMGC flour incorporation. Since DMGC flour has both high water absorbing capacity as well as there was a significant level of fat (around 15\%) found in DMGC flour hence both these factors contributed in a sticky dough thus reducing extensibility of dough. The extensible and cohesive structure is contributed by sugar

\begin{tabular}{|c|c|c|c|c|c|}
\hline $\begin{array}{c}\text { DMGCF in flour } \\
\text { blends (\%) }\end{array}$ & $\begin{array}{c}\text { Appearance } \\
\text { and Colour }\end{array}$ & Flavour & Texture & Taste & $\begin{array}{c}\text { Overall } \\
\text { Acceptability }\end{array}$ \\
\hline 0 & 6.97 & $6.97^{\mathrm{ab}}$ & $6.94^{\mathrm{abc}}$ & $6.97^{\mathrm{ab}}$ & $7.00^{\mathrm{a}}$ \\
\hline 10 & 7.31 & $7.63^{\mathrm{a}}$ & $7.13^{\mathrm{ab}}$ & $7.25^{\mathrm{a}}$ & $7.00^{\mathrm{a}}$ \\
\hline 20 & 7.19 & $6.56^{\mathrm{bc}}$ & $7.30^{8 \mathrm{a}}$ & $6.94^{\mathrm{ab}}$ & $6.91^{\mathrm{a}}$ \\
\hline 30 & 6.72 & $6.63^{\mathrm{bc}}$ & $7.25^{\mathrm{abc}}$ & $6.56^{\mathrm{abc}}$ & $6.88^{\mathrm{a}}$ \\
\hline 40 & 7.13 & $6.50^{\mathrm{bc}}$ & $6.50^{\mathrm{bc}}$ & $6.44^{\mathrm{bc}}$ & $6.50^{\mathrm{ab}}$ \\
\hline 50 & 6.69 & $6.19^{\mathrm{c}}$ & $6.38^{\mathrm{c}}$ & $6.00^{\mathrm{c}}$ & $6.16^{\mathrm{b}}$ \\
\hline
\end{tabular}

Mean values with the same superscript letters within the same column do not diffe significantly $(p>0.05)$

Table 3: Effect of de-oiled maize cake on sensory quality of biscuit fortified with DMGCF.

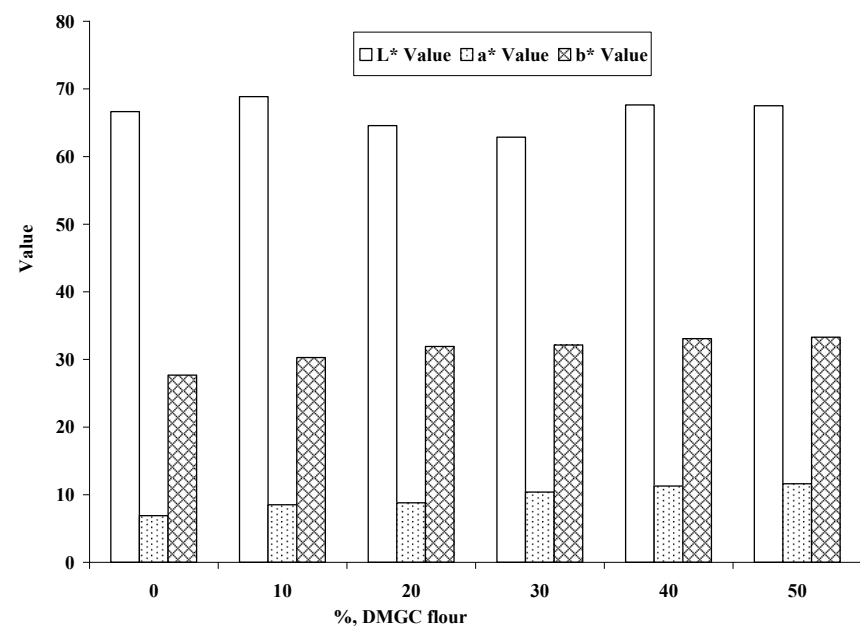

Figure 1: Effect of DMGC flour incorporation on color values of biscuits. 


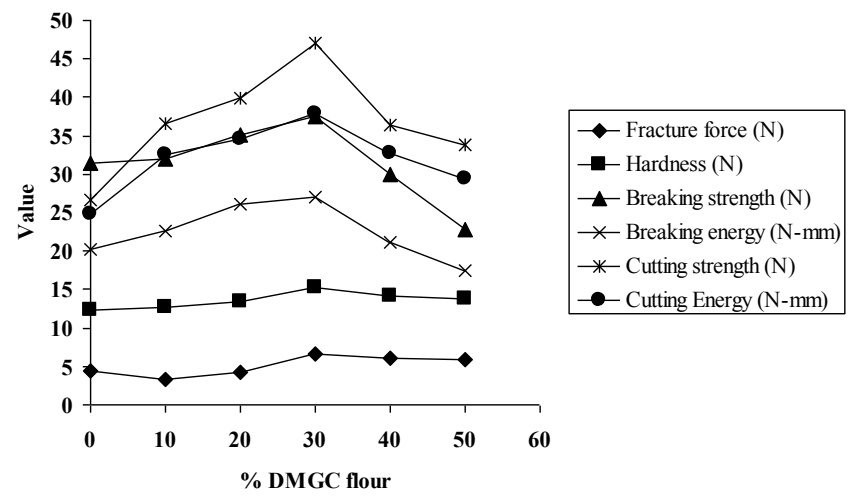

Figure 2: Effect of DMGC flour incorporation on textural parameters of biscuits.

or water interaction with wheat protein thus forming gluten but with an increase in fat content the flour gets coated and this network gets interrupted thus properties of biscuits are changed and a less harder. At very high fat content the lubricating function is high thus less water is required and a softer texture is obtained. Hence the hardness and breaking strength gradually decreased forming a softer biscuits with an increased level of DMGC flour. The values of fracture force $(\mathrm{N})$, hardness $(\mathrm{N})$, breaking strength $(\mathrm{N})$, breaking energy $(\mathrm{N}-\mathrm{mm})$, cutting strength $(\mathrm{N})$ and cutting energy $(\mathrm{N}-\mathrm{mm})$ varied from 3.24-6.61, $12.35-15.22,22.72-37.41,17.42-27.03,26.74-47.04$ and $24.78-37.93$ respectively.

\section{Conclusion}

The addition of DMGC flour resulted in significant increase in protein content in wheat flour-DMGC flour blends. From the above investigation it can be concluded that although biscuits incorporated with $40-50 \%$ replacement of DMGC flour were nutritionally rich they received lower score for different sensory attributes than the ones prepared from $10 \%$. The textural properties showed that the fracture force, hardness, breaking strength, breaking energy, cutting strength and cutting energy increased with DMGC flour incorporation level up to $30 \%$ and then decreased with increase in DMGC flour incorporation level. Incorporation of DMGC flour had a significant effect on color values, lightness decreased while ' $a$ ' and ' $b$ ' values increased producing a darker color with higher levels of DMGC flour. The results obtained could be very valuable in decision making for industries that want to take nutritional advantage of DMGC flour as alternative or supplement to wheat flour. DMGC flour could be useful in the manufacture of highly nutritious biscuits.

\section{References}

1. Sudha ML, Vetrimani $R$, Leelavathi $K$ (2007) Influence of fibre from different cereals on the rheological characteristics of wheat flour dough and on biscuit quality. Food Chem 100: 1365-1370.

2. Chevallier S, Colonna P, Valle DG, Lourdin D (2000) Contribution of Major Ingredients during Baking of Biscuit Dough Systems. J Cereal Sci 31: 241-252.

3. Akoh CC (1998) Fat replacers. J Food Technol 52: 47-53.
4. Anderson RA (1970) Corn wet milling industry. In Corn: Culture, Processing Products; Inglett, G.E.; Ed.; AVI Publications: Newport, CT,USA.

5. Alexander DE (1989) Maize. In Oil Crops; Röbbelen, G.; Downey, R.K.; Ashri, A.; Eds.; McGraw-Hill: New York, USA.

6. Gupta HO, Eggum BO (1998) Processing of maize germ oil cake into edible food grade meal and evaluation of its protein quality. Plant Food Hum Nutr 52: $1-8$

7. Barbieri R, Casiraghi EM (1983) Production of a food grade flour from defatted corn germ meal. Int J Food Sci Tech 18: 35-41.

8. Lawton WJ, Wilson CM (2003) Proteins of the kernel. In Corn: Chemistry and Technology, 2nd ed Amer. Assoc. Cereal Chemists: St. Paul, MN, 314-354.

9. Parris N, Moreau RA, Johnston DB, Singh V, Dickey LC (2006) Protein distribution in commercial wet- and dry-milled corn germ. J Agric Food Chem 54: 4868-4872.

10. Anjum FM, Ahmad I, Butt MS, Sheikh MA, Pasha I (2005) Amino acid composition of spring wheats and losses of lysine during chapati baking. $J$ Food Comp Analysis 18: 523-532.

11. Bhattacharya M, Hanna MA (1985) Extrusion Processing of Wet Corn Gluten Meal. J Food Sci 50: 1508-1509.

12. Kulakova EV, Vainerman ES, Rogozhin SV (1983) Contribution to the investigation of the corn germ. Part II. Chemical composition of germ meal out of corn-oil cake. Nahrung 27: 721-726.

13. Peri C, Barbieri R, Casiraghi EM (1983) Physical, chemical, and nutritional quality of extruded corn germ flour and milk protein blends. Int J Food Sci Technol 18: 43-52.

14. Zayas, JF, Lin CS (1989) Water Retention of Two Types of Hexane-Defatted Corn Germ Proteins and Soy Protein Flour. Cereal Chem 66: 51-55.

15. AOAC (2000) Official Methods of Analysis of AOAC international, American association of cereal chemists Washington D C.

16. Singh S, Riar CS, Saxena DC (2008) Effect of incorporating sweetpotato flour to wheat flour on the quality characteristics of cookies. African J Food Sci 2 65-72.

17. Tyagi SK, Manikantan MR, Oberoi HS, Kaur G (2007) Effect of mustard flou incorporation on nutritional, textural and organoleptic characteristics of biscuits. J Food Eng 4: 1043-1050.

18. Mridula D, Gupta RK, Manikantan MR (2007) Effect of Incorporation of Sorghum Flour to Wheat Flour on Quality of Biscuits Fortified with Defatted Soy Flour. American J Food Technol 2: 428-434.

19. Larmond E (1977) Laboratory Methods for Sensory Evaluation of Foods Canada Department of Agriculture Publication Ottawa.

20. Kumar S, Rekha, Sinha LK (2010) Evaluation of quality characteristics of soy based millet biscuits. Adv App Sci Res 1: 187-196.

21. Srivastava Y (2010) Effect of Virgin Coconut Meal (VCM) on the Textural Thermal and Physico Chemical Properties of Biscuits. Food Nutr Sci 1: 38-44.

22. Gallagher E, Kenny S, Arendt EK (2005) Impact of dairy protein powders on biscuit quality. Eur Food Res Technol 4: 237-243.

23. Singh B, Bajaj M, Kaur A, Sharma S, Sidhu JS (1993) Studies on the development of high-protein biscuits from composite flours. Plant Foods Human Nutr 43: 181-189.

24. Buck JS, Walker CE, Watson KS (1987) Incorporation of Corn Gluten Mea and Soy into Various Cereal-based Foods and Resulting Product Functional Sensory, and Protein Quality. Cereal Chem 64: 264-269.

25. Arshad MU, Anjum FM, Zahoor T (2007) Nutritional assessment of cookies supplemented with defatted wheat germ. Food Chem 102: 123-128. 